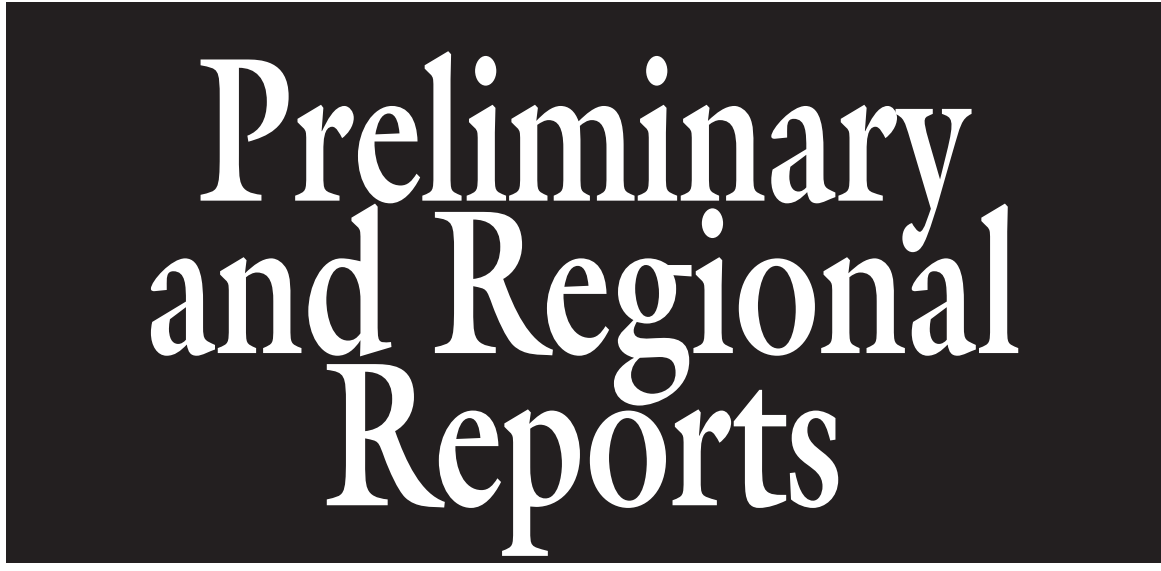

\section{Effect of High Electrical Conductivity of Hydroponic Nutrient Solution on Vaccine Protein Content in Transgenic Tomato}

\author{
Ryo Matsuda ${ }^{1,3,6}$, Chieri Kubota ${ }^{1}$, M. Lucrecia Alvarez ${ }^{2,4}$, \\ and Guy A. Cardineau ${ }^{2,5}$
}

ADDITIONAL INDEX WORDs. controlled environment agriculture, molecular farming, plague, plant-made pharmaceuticals, PMP, Solanum lycopersicum, subunit vaccine

SUMMARY. Using greenhouse tomato (Solanum lycopersicum) as a model system to produce pharmaceutical proteins, electrical conductivity (EC) of hydroponic nutrient solution was examined as a possible factor that affects the protein concentration in fruit. Transgenic tomato plants, expressing Fl-V protein, a plantmade candidate subunit vaccine against plague (Yersinia pestis), were grown hydroponically at high $\left(5.4 \mathrm{dS} \cdot \mathrm{m}^{-1}\right)$ or conventional EC $\left[2.7 \mathrm{dS} \cdot \mathrm{m}^{-1}\right.$ (control) $]$ with a high-wire system in a temperature-controlled greenhouse. There was no significant difference in plant growth and development including final shoot dry weight (DW), leaf area, stem elongation rate, or leaf development rate between high EC and control. Net photosynthetic rate, transpiration rate, and stomatal conductance $\left(g_{s}\right)$ of leaves were also not significantly different between EC treatments. For both EC treatments, immature green fruit accumulated DW at a similar rate, but dynamics observed in fruit total soluble protein (TSP) and Fl-V during the fruit growth were different between the two ECs. Fruit TSP concentration per unit DW decreased while TSP content per whole fruit increased as fruit grew, regardless of EC. However, TSPs were significantly lower in high EC than in control. Fruit F1-V concentration per unit DW and F1-V content per whole fruit were also lower in high EC than in control. Our results found that increasing EC of nutrient solution decreased TSP including the vaccine protein in fruit, suggesting that adjusting nutrient solution EC at an appropriate level is necessary to avoid salinity stress in this transgenic tomato.

$\mathrm{P}$ lant-made pharmaceutical (PMP) protein production or molecular farming is attracting considerable interest as a novel system for production of therapeutic proteins. Using plant-based expression systems, various PMP proteins, including vaccines, antibodies, and other proteins such as hormones, growth factors, blood proteins, cytokines, and enzymes can be synthesized (De Muynck et al., 2010; Matoba et al., 2011; Rybicki, 2010). Several PMP products have been or are to prevent transgene flow to the outside (Twyman et al., 2003), and capability of environmental control for steering the plant growth to maximize the protein productivity with minimum input of available resources (Matsuda et al., 2009).

Alvarez et al. (2006) developed transgenic tomato lines transformed with the $\Upsilon$. pestis fl-p fusion gene encoding the Fl-V fusion protein, a subunit vaccine candidate against bubonic and pneumonic plague, and driven by the constitutive cauliflower mosaic virus (CaMV) $35 \mathrm{~S}$ promoter. They demonstrated with mice that orally delivered freeze-dried fruit of the transgenic plants was immunogenic (Alvarez et al., 2006) and protective against a challenge of $\Upsilon$. pestis (Alvarez and Cardineau, 2010), suggesting that it can be used as an edible vaccine. Our previous studies showed that the transgenic plants grown in a growth chamber (Alvarez et al., 2006) had a 6-fold higher fruit $\mathrm{Fl}-\mathrm{V}$ protein concentration than those in a greenhouse (Matsuda et al., 2009), suggesting that the fruit $\mathrm{Fl}-\mathrm{V}$ protein concentrations were possibly affected by growing conditions, cultural practice, or both. However, partly because protein is not a typical quality attribute in tomato fruit, there is limited information available for environmental and cultural factors affecting fruit protein concentrations. We believe that target protein productivity can be maximized by carefully optimizing environmental conditions around the plants and that inappropriate control of abiotic environments could decrease the production of transgenic proteins in plants. In the commercial context, the optimal environments for PMP production would be indispensable information for enhancing protein productivity per unit area and time or for preventing the potential loss of a protein product.

Stevens et al. (2007) showed that moderate water stress due to less irrigation enhanced the concentration of subunit vaccine candidate against anthrax in leaves of transgenic tobacco (Nicotiana tabacum). Providing water stress to plants by lowering water potential in the root zone is simply, predictably, and economically achievable in greenhouse tomato hydroponics, by increasing the EC of the nutrient solution by adding sodium chloride $(\mathrm{NaCl})(\mathrm{Wu}$ and Kubota, 2008a) and has been commercially practiced to 
improve the flavor in tomato ( $\mathrm{Wu}$ and Kubota, 2008a). Applying low water potential in root zone generally "concentrates" soluble solids in tomato fruit (Adams, 1991; Krauss et al., 2006; Lin and Glass, 1999; Mitchell et al., 1991; Wu et al., 2004; Wu and Kubota, 2008b). Similarly, fruit TSP and Fl-V in fruit may be increased in the transgenic tomato grown under a high EC (more negative water potential in the root zone). However, to our knowledge, there is no information available on the dynamics of TSP or a target protein concentration in tomato fruit under high EC.

The aim of this study was thus to investigate the effects of an increased EC of hydroponic nutrient solution on TSP and Fl-V protein concentrations in fruit of the transgenic tomato grown in a greenhouse. Whole-plant growth and development, and leaf gas exchange characteristics were also evaluated to examine whether there were adverse effects of the high EC (Adams, 1991; Romero-Arande et al., 2001). Results would provide information on how important strict management of nutrient solution EC is for optimizing practical $\mathrm{Fl}-\mathrm{V}$ production with the transgenic tomato in greenhouse.

\section{Materials and methods}

Plant material AND growth CONDITIONS. The primary transformant $\left(T_{0}\right)$ of the transgenic tomato plants expressing $\mathrm{Fl}-\mathrm{V}$ protein had been obtained previously by Agrobacteriummediated transformation of a wild-type 'TA234' with the $\Upsilon$. pestis fl-v fusion

We would like to thank Mark Kroggel and Shawn Fleck for their technical assistance. This work was financially supported in part by Strategic Research Group Planning Grant from Science Foundation Arizona and College of Agriculture and Life Sciences, The University of Arizona.

${ }^{1}$ Controlled Environment Agriculture Center, School of Plant Sciences, College of Agriculture and Life Sciences, The University of Arizona, Tucson, AZ 85721-0036

${ }^{2}$ Center for Infectious Diseases and Vaccinology, The Biodesign Institute, Arizona State University, Tempe, AZ 85287-4501

${ }^{3}$ Current address: Department of Biological and Environmental Engineering, Graduate School of Agricultural and Life Sciences, The University of Tokyo, Bunkyo, Tokyo, 113-8657 Japan

${ }^{4}$ Current address: Diabetes, Cardiovascular and Metabolic Diseases Division, Translational Genomics Research Institute, Phoenix, AZ 85004

${ }^{5}$ Current address: Departamento de Agrobiotecnología y Agronegocios, Tecnológico de Monterrey, Campus Monterrey, Monterrey, Nuevo León, Mexico

${ }^{6}$ Corresponding author. E-mail: amatsuda@mail.ecc. u-tokyo.ac.jp. gene driven by the constitutive CaMV 35 S promoter (Alvarez et al., 2006). One plant of its $T_{1}$ progeny, line 22.11, showing a substantially high Fl-V expression level of $11 \%$ of fruit TSP (Alvarez et al., 2006), was selected and allowed to self-fertilize. One of its $T_{2}$ progeny, line 22.11.5, was selected based on their relatively high $\mathrm{Fl}-\mathrm{V}$ expression levels and on their visual normality, and its cuttings were vegetatively propagated to ensure a genetically homogenate population and were used in the experiment.

After rooted and acclimatized, the plants were grown hydroponically with a high-wire system in an acrylic, Biosafety-Level- 2 greenhouse equipped with evaporative fan-and-pad cooling system in Tucson, AZ, from July to Oct. 2008. Cultivation conditions were described in detail by Matsuda et al. (2010). Briefly, a mixture of 1 perlite:1 vermiculite (by volume) was used as a growth media, placed in 2-gal black plastic pots. A nutrient solution was supplied using a drip irrigation system. The basal composition of the full-strength modified Hoagland nutrient solution was prepared according to $\mathrm{Wu}$ and Kubota (2008b) with slight modifications (Matsuda et al., 2009) except that the concentration of nitrogen, derived from potassium nitrate and calcium nitrate, was $100 \mathrm{mg} \cdot \mathrm{L}^{-1}$. The irrigation volume per application, irrigation frequency, and daily irrigation period when the irrigation took place at the designated irrigation frequency were increased depending on plant growth so as to maintain a minimum of $30 \%$ efflux of the nutrient solution and to avoid nutrient accumulation: from 100 to $200 \mathrm{~mL}$, from once per $60 \mathrm{~min}$ to once per $20 \mathrm{~min}$, and from 7.5 to $9 \mathrm{~h} \cdot \mathrm{d}^{-1}$, respectively. Mean daytime and nighttime air temperatures during the experiment were about 24 and $22{ }^{\circ} \mathrm{C}$, respectively. Daily photosynthetic photon flux $(P P F)$ integral on sunny days was between 15 and 20 $\mathrm{mol} \cdot \mathrm{m}^{-2} \cdot \mathrm{d}^{-1}$ and that on average over the experimental period was about 18 $\mathrm{mol} \cdot \mathrm{m}^{-2} \cdot \mathrm{d}^{-1}$. Trusses below the ninth node were removed before anthesis. Fruit were pruned to seven per truss.

Treatments. On 30 Aug. 2008, when the first trusses above the ninth node were allowed to flower, EC treatments started. The high EC $\left(5.4 \pm 0.3 \mathrm{dS} \cdot \mathrm{m}^{-1}\right)$ was achieved by adding $1.6 \mathrm{~g} \cdot \mathrm{L}^{-1} \mathrm{NaCl}$ to the basic nutrient solution described above. Nutrient solution for the control plants was unamended $\left(2.7 \pm 0.2 \mathrm{dS} \cdot \mathrm{m}^{-1}\right)$. The high EC of $5.4 \mathrm{dS} \cdot \mathrm{m}^{-1}$ was determined because a moderately high EC of around $5 \mathrm{dS} \cdot \mathrm{m}^{-1}$ reportedly increased fruit soluble solids without decreasing leaf photosynthesis and yields in wild-type tomato (Leonardi et al., 2004; Wu and Kubota, 2008a, $2008 \mathrm{~b})$. The EC levels of the nutrient solution tanks were monitored and adjusted if necessary once a day according to the nutrient recipe in each treatment. Six plants were subjected to each treatment.

Gas eXCHANGE MEASUREMENTS. Measurements of net photosynthetic rate $\left(P_{\mathrm{n}}\right)$, transpiration rate and $g_{\mathrm{S}}$ in young, fully expanded leaves were carried out using a portable photosynthesis system equipped with a halogen light source (CIRAS-2; PP Systems, Amesbury, MA) between 5 and 7 Oct. 2008. Measurements were made under saturating light conditions at a $P P F$ of $1500 \mu \mathrm{mol} \cdot \mathrm{m}^{-2} \cdot \mathrm{s}^{-1}$, an atmospheric carbon dioxide concentration of $340 \pm 10 \mathrm{ppm}$ which was close to that inside the greenhouse, a leaf temperature of $28{ }^{\circ} \mathrm{C}$, and a leaf-to-air vapor pressure deficit of $1.2 \pm 0.2 \mathrm{kPa}$.

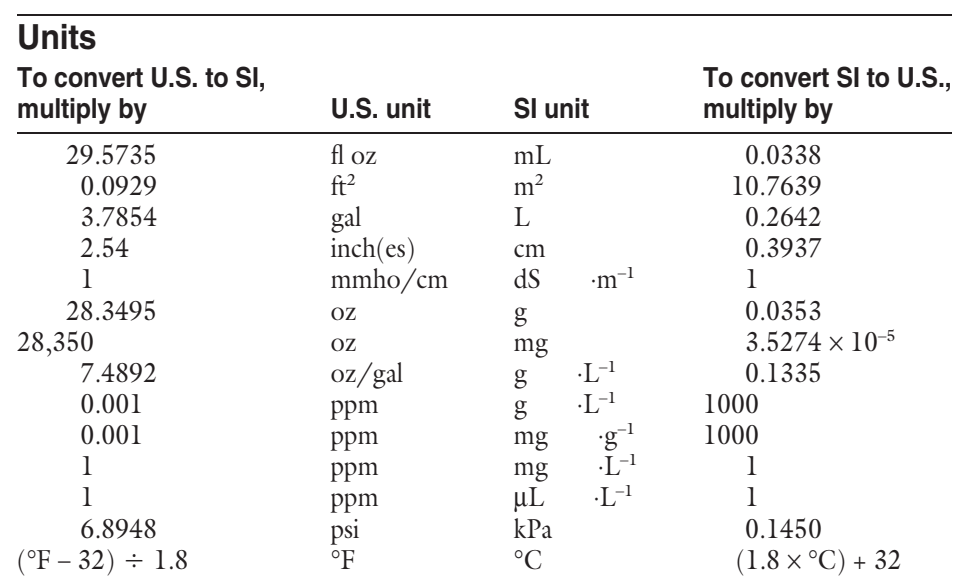


After the measurements, leaves were detached, weighed, and kept at $-80^{\circ} \mathrm{C}$ until TSP analysis.

GROWTH ANALYSIS AND FRUIT HARVEST. Stem length and leaf number were measured once a week from 14 Sept. 2008. The rates of stem elongation and leaf development of each plant were calculated as the slopes of the first-order regression equation of time courses of stem length and leaf number, respectively. On 15 Oct. 2008 , shoot (leaves and stem, without fruit, above the base of the 10th youngest leaf) was detached, and leaf area and DW of leaves and stem were measured. Leaf area measurement was made with an area meter (LI-3100; LI-COR, Lincoln, NE).

All fruit on the first and second trusses of each plant were harvested at one time on 9 Oct. 2008. The fruit at various growth and developmental stages was classified into six ripeness stages (green, breaker, turning, pink, light red, and red stages) based on the color classification for fresh tomatoes (U.S. Department of Agriculture, 1991). As fruit Fl-V rapidly decreases with ripening (Alvarez et al., 2006), only green fruit was used for subsequent growth and biochemical analyses. Fruit between the breaker stage (more than 90\% fruit surface in green) and red stage (no longer green) was only used for calculating fruit growth index (FGI) of a green fruit as described below. The fresh weight (FW) and the longest diameter on the equatorial plane of the green fruit were measured. The fruit was then divided longitudinally into three portions through the stem scar and FW of each portion was measured. The three portions were subjected to determination of DW and TSP and Fl-V concentrations. Fruit DW was determined after ovendried at $80^{\circ} \mathrm{C}$ for at least $5 \mathrm{~d}$, and dry matter percentage (DW/FW) was used for calculating DW per whole fruit. Another portion for TSP determination was kept at $-80{ }^{\circ} \mathrm{C}$ until analysis. The portion for Fl-V determination was kept at $-80{ }^{\circ} \mathrm{C}$, freeze-dried for at least $72 \mathrm{~h}$, pulverized to powder, vacuum-sealed, and stored until analysis.

We defined FGI as an indicator of fruit growth for a green fruit, which is the relative fruit diameter of the fruit to the maximum diameter estimated as the mean diameter of fruit between the breaker and red stage (Matsuda et al., 2010).
Biochemical assays. TSP was extracted from leaves and fruit as described in Matsuda et al. (2009), and its concentration was determined by the method of Lowry et al. (1951) using bovine serum albumin as a standard. Fruit Fl-V concentration was determined by enzyme-linked immunosorbent assay using a rabbit polyclonal anti-Fl-V antibody as described in Alvarez et al. (2006).

Data analysis. Significant differences between treatments were tested by $t$ test at $P<0.05 \mathrm{using}$ statistical software (JMP 9.0.3; SAS Institute, Cary, NC). First- or thirdorder regression was applied to the relationship between fruit characteristics and FGI where it was significant $(P<0.05)$. Significant differences between treatments in slopes and intercepts in first-order regression equations were tested by analysis of covariance [ANCOVA (Sokal and Rohlf, 1995)] at $P<0.05$ using the same software.

\section{Results and discussion}

EC did not significantly affect the plant growth and development in the present experiment. There was no significant difference between control and high EC in shoot DW, shoot dry matter, total leaf area, stem elongation rate, or leaf development rate (Table 1 ). Also, $P_{\mathrm{n}}$, transpiration rate, and $g_{s}$ per unit leaf area and leaf TSP concentration per unit DW were not significantly different between treatments (Table 2). These results indicate that the EC level in the high EC treatment $\left(5.4 \mathrm{dS} \cdot \mathrm{m}^{-1}\right)$ was relatively mild and not as high as that negatively affecting growth and development of whole plant and the leaf characteristics. Similar results were reported by Wu et al. (2004) and Wu and Kubota (2008a).

Because we previously found that fruit TSP and Fl-V concentrations per unit DW markedly decreased with fruit growth during the green stage in this transgenic tomato (Matsuda et al., 2010), fruit TSP and Fl-V concentrations were compared at various growth stages defined by the fruit size. We defined FGI as an indicator of fruit growth for a green fruit (Matsuda et al., 2010). Similar diameter-based evaluation of the physiological change in developing tomato fruit was also reported by Eltayeb and Roddick (1984). They showed almost the same

Table 1. Mean shoot dry weight, shoot dry matter, and total leaf area at the end of experiment and rates of stem elongation and leaf development of transgenic tomato grown at conventional (control) or high electrical conductivity (EC); $n=3-6$.

\begin{tabular}{|c|c|c|c|c|c|}
\hline Treatment $^{z}$ & $\begin{array}{c}\text { Shoot dry } \\
\text { wt }(\mathrm{g} / \text { plant })^{\mathrm{y}}\end{array}$ & $\begin{array}{l}\text { Shoot dry } \\
\text { matter (\%) }\end{array}$ & $\begin{array}{c}\text { Total } \\
\text { leaf area } \\
\left(\mathrm{m}^{2} / \text { plant }\right)^{\mathrm{y}}\end{array}$ & $\begin{array}{c}\text { Stem } \\
\text { elongation } \\
\text { rate }\left(\mathrm{cm} \cdot \mathrm{d}^{-1}\right)^{\mathrm{y}}\end{array}$ & $\begin{array}{c}\text { Leaf } \\
\text { development } \\
\text { rate }(\text { no. } / \mathrm{d})^{\mathrm{y}}\end{array}$ \\
\hline Control & 16.8 & 13.0 & 0.129 & 2.23 & 0.47 \\
\hline High EC & 14.8 & 12.5 & 0.130 & 2.24 & 0.51 \\
\hline$t$ test & NS & NS & NS & NS & NS \\
\hline
\end{tabular}

${ }^{\mathrm{z}}$ Control $=2.7 \mathrm{dS} \cdot \mathrm{m}^{-1}$, high $\mathrm{EC}=5.4 \mathrm{dS} \cdot \mathrm{m}^{-1} ; \mathrm{ldS} \cdot \mathrm{m}^{-1}=1 \mathrm{mmho} / \mathrm{cm}$.

${ }^{\mathrm{y}} \mathrm{l} \mathrm{g}=0.0353 \mathrm{oz}, \mathrm{l} \mathrm{m}^{2}=10.7639 \mathrm{ft}^{2}, \mathrm{l} \mathrm{cm}=0.3937$ inch.

NS $=$ NS at $P<0.05$.

Table 2. Mean net photosynthetic rate $\left(P_{\mathrm{n}}\right)$, transpiration rate, stomatal conductance $\left(g_{s}\right)$ per unit leaf area, and total soluble protein (TSP) concentration per unit dry weight of young, fully expanded leaves of transgenic tomato grown at conventional (control) or high electrical conductivity (EC); $n=3-6$.

\begin{tabular}{lcccc}
\hline Treatment $^{\mathbf{z}}$ & $\begin{array}{c}\boldsymbol{P}_{\mathbf{n}} \\
\left(\boldsymbol{\mu m o l} \cdot \mathbf{m}^{-2} \cdot \mathbf{s}^{-\mathbf{l}}\right)^{\mathbf{y}}\end{array}$ & $\begin{array}{c}\text { Transpiration rate } \\
\left(\mathbf{m m o l} \cdot \mathbf{m}^{-2} \cdot \mathbf{s}^{-1}\right)^{\mathbf{y}}\end{array}$ & $\begin{array}{c}g_{\mathrm{s}} \\
\left(\mathbf{m o l} \cdot \mathbf{m}^{-2} \cdot \mathbf{s}^{-1}\right)^{\mathbf{y}}\end{array}$ & $\begin{array}{c}\text { Leaf TSP concn } \\
\left(\mathbf{m g} \cdot \mathbf{g}^{-1} \mathbf{d r y ~ w t}\right)^{\mathbf{x}}\end{array}$ \\
\hline Control & 9.08 & 5.62 & 0.280 & 105 \\
High EC & 9.01 & 5.72 & 0.290 & 114 \\
$t$ test & $\mathrm{NS}$ & $\mathrm{NS}$ & $\mathrm{NS}$ & $\mathrm{NS}$ \\
\hline
\end{tabular}

${ }^{\mathrm{z}}$ Control $=2.7 \mathrm{dS} \cdot \mathrm{m}^{-1}$, high $\mathrm{EC}=5.4 \mathrm{dS} \cdot \mathrm{m}^{-1} ; \mathrm{ldS} \cdot \mathrm{m}^{-1}=1 \mathrm{mmho} / \mathrm{cm}$

${ }^{y}$ Measurements were made under saturating light conditions at a photosynthetic photon flux of $1500 \mu \mathrm{mol} \cdot \mathrm{m}^{-2} \cdot \mathrm{s}^{-1}$, an atmospheric carbon dioxide concentration of $340 \mathrm{ppm}\left(\mu \mathrm{L} \cdot \mathrm{L}^{-1}\right)$, a leaf temperature of $28^{\circ} \mathrm{C}\left(82.4^{\circ} \mathrm{F}\right)$ and a leafto-air vapor pressure deficit of $1.2 \mathrm{kPa}(0.174 \mathrm{psi})$.

${ }^{\mathrm{x}} \mathrm{l} \mathrm{mg} \cdot \mathrm{g}^{-1}=1000 \mathrm{ppm}$.

NS $=$ NS at $P<0.05$. 


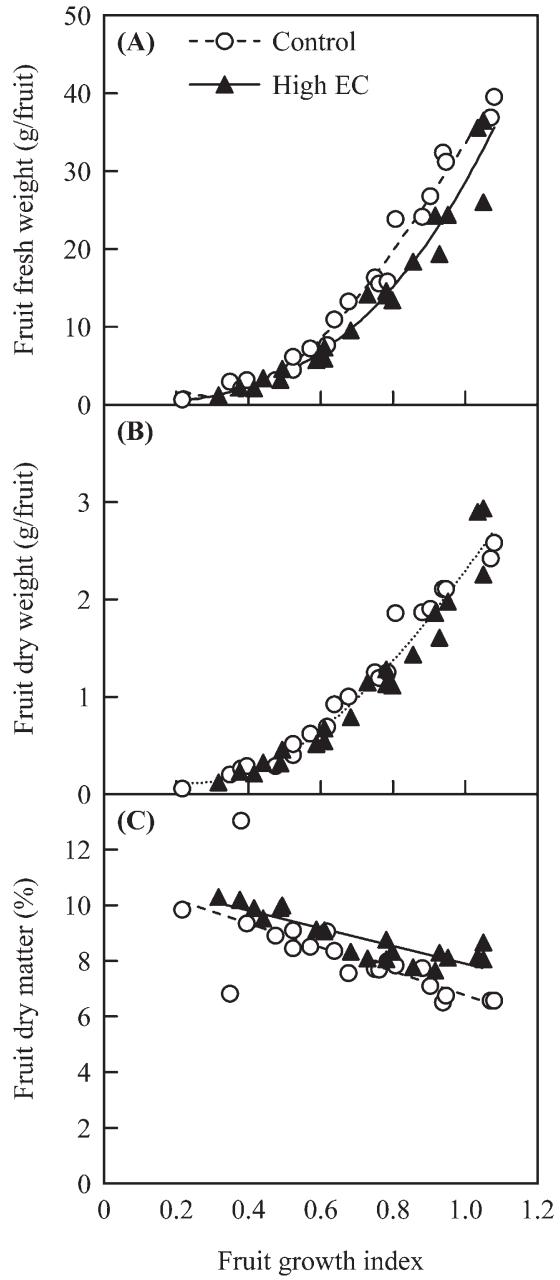

Fig. 1. The relationship between fruit (A) fresh weight, (B) dry weight, or (C) dry matter and fruit growth index [FGI (relative fruit diameter to the estimated maximum)] in green fruit of the transgenic tomato grown in control treatment [2.7 $\mathrm{dS} \cdot \mathrm{m}^{-1}$ (open circle)] or high electrical conductivity (EC) [5.4 $\mathrm{dS} \cdot \mathrm{m}^{-1}$ (closed triangle)]. Actual fruit diameter at a FGI of 1 was $4.5 \mathrm{~cm}$ for control and $4.2 \mathrm{~cm}$ for high EC. Data for control were presented in Matsuda et al. (2010). (A) $y=-44.9 x^{3}+139 x^{2}-$ $72.2 x+11.4, r^{2}=0.983, P<0.05$ [control (dashed line)]; $y=24.7 x^{3}+$ $3.89 x^{2}-0.281 x+0.193, v^{2}=0.953, P<$ 0.05 [high EC (solid line)]. (B) $y=$ $-1.32 x^{3}+5.84 x^{2}-2.65 x+0.432, r^{2}=$ $0.960, P<0.05$ [control and high EC (dotted line)]. (C) $y=-4.30 x+11.1, v^{2}=$ 0.495 (control); $y=-3.19 x+11.1, v^{2}=$ $0.760, P<0.05$ (high EC) $1 \mathrm{dS} \cdot \mathrm{m}^{-1}=1$ $\mathrm{mmho} / \mathrm{cm}, 1 \mathrm{~cm}=0.3937$ inch, $1 \mathrm{~g}=$ $0.0353 \mathrm{oz}$.

pattern of the change in fruit alkaloid content irrespective of its expression based on fruit diameter or the days after anthesis, indicating that diameter-

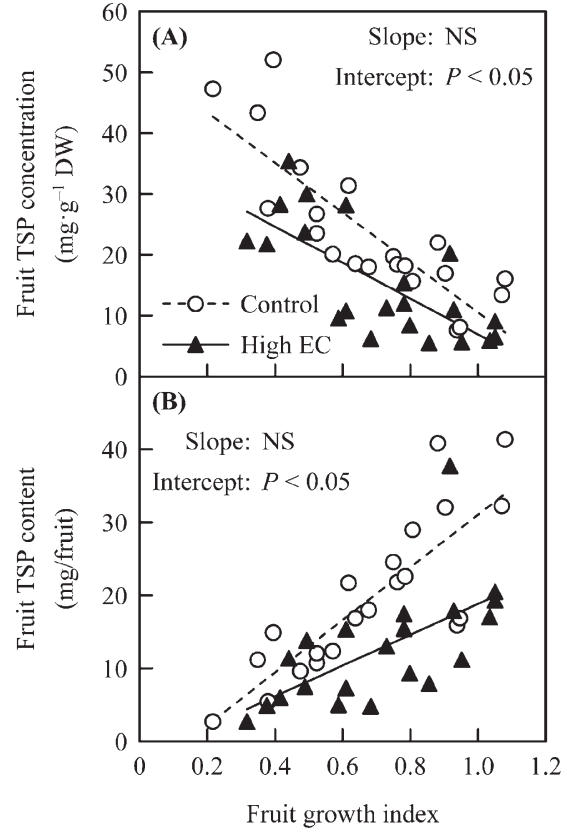

Fig. 2. The relationship between fruit (A) total soluble protein (TSP) concentration per unit dry weight (DW) or (B) TSP content per fruit and fruit growth index [FGI (relative fruit diameter to the estimated maximum)] in green fruit of the transgenic tomato grown in control treatment $\left[2.7 \mathrm{dS} \cdot \mathrm{m}^{-1}\right.$ (open circle)] or high electrical conductivity (EC) $\left[5.4 \mathrm{dS} \cdot \mathrm{m}^{-1}\right.$ (closed triangle)]. Actual fruit diameter at a FGI of 1 was $4.5 \mathrm{~cm}$ for control and $4.2 \mathrm{~cm}$ for high EC. Data for control were presented in Matsuda et al. (2010). (A) $y=-41.2 x+51.7, v^{2}=0.755, P<$ 0.05 [control (dashed line)]; $y=$ $-29.5 x+36.5, v^{2}=0.608, P<0.05$ [high EC (solid line)]. (B) $y=36.1 x-$ 5.0, $v^{2}=0.677, P<0.05$ (control); $y=$ $21.2 x-2.4, r^{2}=0.393, P<0.05$ (high EC). The result of analysis of covariance is shown in each panel. Ns: not significant $(P \geq 0.05) ; 1 \mathrm{dS} \cdot \mathrm{m}^{-1}=1$ $\mathrm{mmho} / \mathrm{cm}, 1 \mathrm{~cm}=0.3937$ inch, 1 $\mathrm{mg} \cdot \mathrm{g}^{-1}=1000 \mathrm{ppm}, 1 \mathrm{mg}=3.5274 \times$ $10^{-5} \mathrm{oz}$.

based evaluation of fruit physiological dynamics is almost equivalent to timebased evaluation. The maximum diameter for high EC was (mean $\pm \mathrm{SE}$ ) $4.2 \pm$ $0.1 \mathrm{~cm}$ and slightly smaller than that for control, $4.5 \pm 0.1 \mathrm{~cm}$.

Green fruit FW at a given FGI was slightly lower in high EC than in control at a given FGI (Fig. IA), while green fruit for both control and high EC showed a similar increase in DW when plotted against FGI (Fig. 1B). This was because green fruit dry

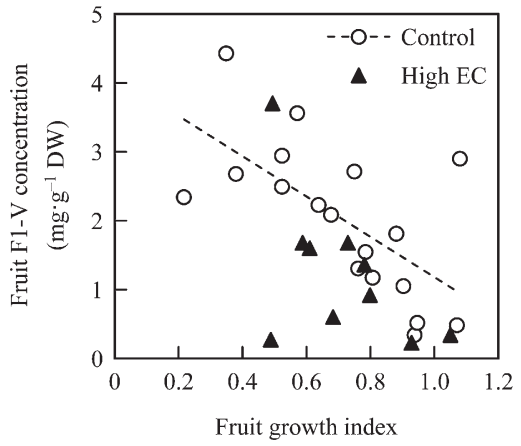

Fig. 3. The relationship between fruit Fl-V (candidate plague vaccine protein) concentration per unit dry weight (DW) and fruit growth index [FGI (relative fruit diameter to the estimated maximum)] in green fruit of the transgenic tomato grown in control $\left[2.7 \mathrm{dS} \cdot \mathrm{m}^{-1}\right.$ (open circle)] or high electrical conductivity (EC) $[5.4$ $\mathrm{dS} \cdot \mathrm{m}^{-1}$ (closed triangle)] treatment. Actual fruit diameter at a FGI of 1 was $4.5 \mathrm{~cm}$ for control and $4.2 \mathrm{~cm}$ for high EC. Data for control were presented in Matsuda et al. (2010). $y=-2.94 x+4.12, r^{2}=0.428, P<0.05$ [control (dashed line)]. No significant correlation in high EC. $1 \mathrm{dS} \cdot \mathrm{m}^{-1}=$ $1 \mathrm{mmho} / \mathrm{cm}, 1 \mathrm{~cm}=0.3937$ inch, $1 \mathrm{mg} \cdot \mathrm{g}^{-1}=1000 \mathrm{ppm}$.

matter percentage was higher in high EC (Fig. 1C). Such an increase in fruit dry matter percentage (or a decrease in fruit water content) under high EC conditions has been frequently observed (Adams, 1991; Adams and Ho, 1989). There also was a slight difference in red fruit FW between high EC $[($ mean $\pm \mathrm{sE}) 30.5 \pm 1.8 \mathrm{~g}]$ and control $(36.8 \pm 3.5 \mathrm{~g})$, although it was not statistically significant, suggesting that the decrease in fruit water content in high EC was not so large as to have led to a significant FW-based yield decrease. We did not observe any physiological disorders on fruit such as blossom-end rot.

Fruit TSP concentration per unit DW decreased as FGI increased in both control and high EC (Fig. 2A). On the other hand, TSP content per whole fruit linearly increased with increasing FGI (Fig. 2B), indicating that dry matter accumulation had a greater impact on TSP content than the decrease in TSP concentration. In either relationship, the intercept of the first-order regression equation was significantly smaller in high EC than in control, while there was 
Table 3. Mean Fl-V (candidate plague vaccine protein) concentration per unit dry weight and F1-V content per fruit for green fruit (all growth stages) of transgenic tomato grown at conventional (control) or high electrical conductivity (EC); $n=18$ (control), $n=10$ (high EC).

\begin{tabular}{lcc}
\hline Treatment $^{\mathrm{z}}$ & $\begin{array}{c}\mathrm{Fl}-\mathrm{V} \text { concn } \\
\left(\mathbf{m g} \cdot \mathbf{g}^{-1} \text { dry wt }\right)^{\mathrm{y}}\end{array}$ & $\begin{array}{c}\text { Fl-V content } \\
(\mathbf{m g} / \text { fruit })^{\mathrm{y}}\end{array}$ \\
\hline Control & 2.02 & 1.37 \\
High EC & 1.24 & 0.77 \\
$t$ test & $*$ & $*$ \\
\hline
\end{tabular}

${ }^{\mathrm{z}}$ Control $=2.7 \mathrm{dS} \cdot \mathrm{m}^{-1}$, high EC $=5.4 \mathrm{dS} \cdot \mathrm{m}^{-1} ; \mathrm{l} \mathrm{dS} \cdot \mathrm{m}^{-1}=1 \mathrm{mmho} / \mathrm{cm}$.

${ }^{\mathrm{y}} \mathrm{l} \mathrm{mg} \cdot \mathrm{g}^{-1}=1000 \mathrm{ppm}, 1 \mathrm{mg}=3.5274 \times 10^{-5} \mathrm{oz}$

*indicates significant at $P<0.05$.

no significant difference in slope by ANCOVA. This means that, at a given FGI, both TSP concentration and content in high EC were significantly lower than those in control. These results indicate that the high EC treatment decreased overall soluble proteins at a given FGI.

Figure 3 shows the relationship between Fl-V concentration per unit DW and FGI. Fl-V concentration decreased linearly as fruit grew in control. Although it also tended to decrease with increasing FGI in high EC treatment, no statistically clear relationship was observed. The reason why Fl-V concentration linearly decreased in control but not in high EC is unclear. There was no apparent correlation between Fl-V content per whole fruit and FGI for both control and high EC treatment (data not shown). As ANCOVA could not be applied to Fl-V concentration per unit DW and Fl-V content per whole fruit for comparison of control and high EC, averages over entire green stage were calculated (Table 3 ). Both Fl-V concentration and content were significantly higher in control than in high EC. Thus, our results indicated that the high EC treatment decreased overall soluble proteins including $\mathrm{Fl}-\mathrm{V}$ compared with the control.

To summarize the results, the high EC treatment applied here did not alter plant growth, development, leaf gas exchange, or fruit dry matter accumulation, but did specifically lower fruit TSP concentration including $\mathrm{Fl}-\mathrm{V}$ concentration per unit DW and their contents per whole fruit in the transgenic tomato. Generally, in salt- and water-stressed parts of a plant, the protein content can decrease owing to the decreased rate of protein synthesis, the increased rate of proteolysis, or both (Dubey, 1999). This could be at least partly responsible for the lower TSP and Fl-V concentration observed in the high EC treatment. Our results suggest that adjustment of nutrient solution EC at an appropriate level is necessary for preventing salinity stress to the plant and a subsequent decrease in fruit soluble proteins including Fl-V. This reduction in vaccine protein yields occurred with a moderate salinity stress, with no apparent negative effect on growth and development, requiring us to manage nutrient supply carefully. Although moderate water stress was reportedly effective in enhancing the amount of subunit vaccine candidate against anthrax in leaves of transgenic tobacco (Stevens et al., 2007), moderate salinity stress was not effective or even had a negative influence in our transgenic tomato fruit.

\section{Literature cited}

Adams, P. 1991. Effects of increasing the salinity of the nutrient solution with major nutrients or sodium chloride on the yield, quality and composition of tomatoes grown in rockwool. J. Hort. Sci. 66:201-208.

Adams, P. and L.C. Ho. 1989. Effects of constant and fluctuating salinity on the yield, quality and calcium status of tomatoes. J. Hort. Sci. 64:725-732.

Alvarez, M.L. and G.A. Cardineau. 2010. Prevention of bubonic and pneumonic plague using plant-derived vaccines. Biotechnol. Adv. 28:184-196.

Alvarez, M.L., H.L. Pinyerd, J.D. Crisantes, M.M. Rigano, J. Pinkhasov, A.M. Walmsley, H.S. Mason, and G.A. Cardineau. 2006. Plant-made subunit vaccine against pneumonic and bubonic plague is orally immunogenic in mice. Vaccine 24:24772490.
De Muynck, B., C. Navarre, and M. Boutry. 2010. Production of antibodies in plants: Status after twenty years. Plant Biotechnol. J. 8:1-35.

Dubey, R.S. 1999. Protein synthesis by plants under stressful conditions, p. 365397. In: M. Pessarakli (ed.). Handbook of plant and crop stress. 2nd ed. Marcel Dekker, New York.

Eltayeb, E.A. and J.G. Roddick. 1984. Changes in the alkaloid content of developing fruits of tomato (Lycopersicon esculentum Mill.). I. Analysis of cultivars and mutants with different ripening characteristics. J. Expt. Bot. 35:252-260.

Krauss, S., W.H. Schnitzler, J. Grassmann, and M. Woitke. 2006. The influence of different electrical conductivity values in a simplified recirculating soilless system on inner and outer fruit quality characteristics of tomato. J. Agr. Food Chem. 54:441448.

Leonardi, C., M. Martorana, F. Giuffrida, V. Fogliano, and R. Pernice. 2004. Tomato fruit quality in relation to the content of sodium chloride in the nutrient solution. Acta Hort. 659:769774 .

Lin, W.C. and A.D.M. Glass. 1999. The effects of $\mathrm{NaCl}$ addition macronutrient concentration on fruit quality and flavor volatiles of greenhouse tomato. Acta Hort. 481:487-493.

Lowry, O.H., N.J. Rosebrough, A.L. Farr, and R.J. Randall. 1951. Protein measurement with the Folin phenol reagent. J. Biol. Chem. 193:265-275.

Mason, H.S., H. Warzecha, T. Mor, and C.J. Arntzen. 2002. Edible plant vaccines: Applications for prophylactic and therapeutic molecular medicine. Trends Mol. Med. 8:324-329.

Matoba, N., K.R. Davis, and K.E. Palmer. 2011. Recombinant protein expression in Nicotiana. Methods Mol. Biol. 701:199219.

Matsuda, R., C. Kubota, M.L. Alvarez, and G.A. Cardineau. 2009. Biopharmaceutical protein production under controlled environments: Growth, development, and vaccine productivity of transgenic tomato plants grown hydroponically in a greenhouse. HortScience 44:15941599.

Matsuda, R., C. Kubota, M.L. Alvarez, and G.A. Cardineau. 2010. Determining the optimal timing of fruit harvest in transgenic tomato expressing $\mathrm{Fl}-\mathrm{V}$, a candidate subunit vaccine against plague. HortScience 45:347-351.

Mitchell, J.P., C. Slientian, and S.R. Grattan. 1991. Developmental changes 
in tomato fruit composition in response to water deficit and salinity. Physiol. Plant. 83:177-185.

Romero-Arande, R., T. Soria, and J. Cuartero. 2001. Tomato plant-water uptake and plant-water relationships under saline growth conditions. Plant Sci. 160:265-272.

Rybicki, E.B. 2010. Plant-made vaccines for humans and animals. Plant Biotechnol. J. 8:620-637.

Sokal, R.R. and F.J. Rohlf. 1995. Biometry. 3rd ed. Freeman, New York.

Stevens, G., E. Vories, M. Mulesky, M. Rhine, and D. Dunn. 2007. Irrigation to maximize vaccine antigen production in genetically modified tobacco. Agron. J. 99:1271-1277.
Strohl, W.R. and D.M. Knight. 2009. Discovery and development of biopharmaceuticals: Current issues. Curr. Opin. Biotechnol. 20:668-672.

Twyman, R.M., E. Stoger, S. Schilliberg, P. Christou, and R. Fischer. 2003. Molecular farming in plants: Host systems and expression technology. Trends Biotechnol. 21:570-578.

U.S. Department of Agriculture. 1991. United States standards for grades of fresh tomatoes. U.S. Dept. Agr., Agr. Mktg. Serv., Washington, DC.

Wu, M. and C. Kubota. 2008a. Effects of electrical conductivity of hydroponic nutrient solution on leaf gas exchange of five greenhouse tomato cultivars. HortTechnology 18:271-277.
Wu, M. and C. Kubota. 2008b. Effects of high electrical conductivity of nutrient solution and its application timing on lycopene, chlorophyll and sugar concentrations of hydroponic tomatoes during ripening. Sci. Hort. 116:122-129.

Wu, M., J.S. Buck, and C. Kubota. 2004. Effects of nutrient solution EC, plant microclimate and cultivars on fruit quality and yield of hydroponic tomatoes (Lycopersicon esculentum). Acta Hort. 659:541-547.

Yusibov, V., S.J. Streatfield, and N. Kushnir. 2011. Clinical development of plant-produced recombinant pharmaceuticals: Vaccines, antibodies and beyond. Hum. Vaccin. 7:313-321. 